\title{
Pathogenesis of chronic pancreatitis
}

\author{
H. SARLES, MD, J.P. BERNARD, MD
}

\begin{abstract}
Studies from the Marseille group allowed differentiation of acute pancreatitis (a group of lesions secondary to either extrapancreatic causes such as gallstones or to pancreatic diseases such as cancer and chronic pancreatitis), from chronic pancreatitis. Two forms of chronic pancreatitis are easily distinguished: obstructive pancreatitis secondary to pre-existing obstruction on pancreatic ducts (tumours, scars, etc); and the most frequent disease, chronic calcifying pancreatitis, which is a pancreatic lithiasis due to a double phenomenon. This double phenomenon is the precipitation of insoluble calcium salts and the precipitation of degraded fragments of a newly discovered secretory protein known as pancreatic stone protein (PSP), This family of glycoproteins, the amino acid sequence of which has been established, is synthesized by the pancreatic acinar cell and its biosynthesis is decreased in patients presenting with chronic calcifying pancreatitis. The secretory form of PSP prevents the formation of calcium salt crystals in the pancreatic juice which is normally supersaturated in calcium. Though the lesions and the secretory modifications of PSP are common to all forms of chronic calcifying pancreatitis, there are different etiological forms of the disease; alcoholic, tropical, hypercalcemic, hereditary and idiopathic. Alcohol consumption acts on pancreatic secretion by different mechanisms and is responsible for an increased secretion of secretory protein (enzymes) due to cholinergic, vagal reflexes sensitive to ethanol. Alcohol consumption is generally associated with protein rich and either fat rich or fat poor diets, both of which are risk factors. Hypercalcemia also increases the secretion of protein and the viscosity of pancreatic juice. The tropical form is not due, as previously suggested, to cassava (manioc) consumption or kwashiorkor, but it is endemic in populations submitted to fat poor, protein poor diets. These etiological factors are only acting on predisposed patients. This suggests that a low or abnormal biosynthesis of PSP is responsible for the predisposition. Can J Gastroenterol 1989;3(1):15-20 (Pour résumé, voir page 16)
\end{abstract}

Key Words: Chronic pancreatitis, Pancreatic stone protein

Clinique des Maladies de l'Appareil Digestif et de la Nutrition, Hôpital Sainte-Marguerite

Correspondence and reprints: Dr Henri Sarles, Inserum U 31-46, Boulevard de la Gaye, 13258

Marseille, Cedex 09, France

Received for publication May 25, 1988. Accepted September 2, 1988
A

CUTE AND CHRONIC PANCREATITIS are considered by some authors as different stages of the same disease, the recurrence of acute pancreatitis being the origin of chronic pancreatitis (1). Studies have shown, however, that acute lesions healed without sequelae after a short stage of reversible fibrosis (2-5). Furthermore, the age of patients presenting with acute pancreatitis, the presumed cause, is 13 years older than that of patients with chronic pancreatitis, the presumed consequence, and etiological data of both groups of patients are significantly different (6). This has been the basis of the two Marseille classifications $(7,8)$ which distinguish acute and chronic pancreatitis as has already been done in classical books (9).

Acute pancreatitis is not a disease but a group of anatomical lesions: edema, necrosis, hemorrhagic necrosis and fatty necrosis. It is frequently due to an extrapancreatic cause such as gallstones but is often a complication of chronic pancreatic diseases, such as pancreatic cancer or chronic pancreatitis. When the cause of these lesions persists, acute pancreatitis may recur but will heal without sequelae if its cause, for instance gallstones, is treated with success. 
RESUME: Les travaux du groupe de Marseille ont permis d'individualiser: des pancréatites aiguës qui sont un groupe de lésions secondaires à des causes soit extrapancréatiques (par exemple la lithiase biliaire) soit intrapancréatiques (compliquant par exemple les pancréatites chroniques); des pancréatites chroniques qui sont un groupe de maladies au sein duquel on peut déjà séparer des pancréatites obstructives dues à un obstacle sur les voies pancréatiques pré-existant à la maladie (cancer, cicatrice, etc) et des pancréatites chroniques calcifiantes, de beaucoup les plus fréquentes. Celles ci sont en réalité une lithiase pancréatique due à un double phénomène, d'abord microscopique puis macroscopique: précipitation de carbonate de calcium et précipitation d'un fragment dégradé d'une molécule sérétoire nouvellement découverte, la PSP (protéine stabilisatrice du pancréas). Cette famille de glycoprotéines dont la séquence en aminoacides est actuellement connue est synthétisée par la cellule acineuse du pancréas et sa synthèse diminuée dans les pancréatites chroniques calcifiantes. La forme sécrétoire de PSP prévient la formation de cristaux de sels de calcium dans le suc pancréatique qui est normalement sursaturé en calcium. Bien que les lésions et les modifications de la PSP soient semblables dans toutes les formes de pancréatite calcifiante, il existe plusieurs étiologies: alcoolique, tropicale, hypercalcémie, héréditaire et idiopathique. L'alcool agit sur la sécrétion pancréatique par des mécanismes divers, essentiellement une hypersécrétion de protéines (enzymes) due à un réflexe long cholinergique empruntant le nerf vague. Lalcoolisme est généralement associé à des régimes hyperprotidiques et soit hyper-, soit hypolipidiques qui sont autant de facteurs de risque. L'hypercalcémie augmente également la sécrétion de protéines enzymatiques. La forme tropicale ne parait être liée ni à la consommation de manioc ou cassava, ni au kwashiorkor mais s'observe dans des zones où l'ensemble de la population est soumise à un régime pauvre en protides et en lipides. Ces facteurs étiologiques n'agissent que sur des sujets prédisposés. Il est possible que la prédisposition soit une baisse de la biosynthèse ou une synthèse anormale de PSP.

Chronic pancreatitis is characterized by persisting destruction of pancreatic parenchyma replaced by fibrosis. Whatever their type, and particularly during the first years of its evolution, it is frequently complicated by bouts of acute pancreatitis which progressively regress when the exocrine pancreatic insufficiency is installed (10-12).

It is now possible to distinguish different forms of chronic pancreatitis presenting with different and specific lesions and etiologies (13-16).

Obstructive pancreatitis: Obstructive pancreatitis is due to the occlusion of the main pancreatic duct, or of one of its branches, before the area of pancreatitis, for example, tumours, fibrous scars of necrotic pseudocysts, or congenital anomalies. The lesions are regularly sprayed in the occluded territories, the duct epithelium is relatively preserved, pancreatic calculi are not found and protein precipitates are rare.

Calcifying chronic pancreatitis (CCP): CCP is by far the most frequent form of chronic pancreatitis, representing more than $95 \%$ of cases. Though $\mathrm{CCP}$ is due to different causes (alcoholism, tropical juvenile form, hereditary, hypercalcemia, idiopathic), its lesions are similar regardless of etiology $(13,15,16)$. They are characterized by their patchy distribution: the intensity of the lesions of one lobule or group of lobules (and of the duct draining them) is different from neighbouring lobules, varying from a completely normal appearance to complete destruction. Duct lesions are important: atrophy of epithelium, scars with formation of strictures and of retention cysts and deformation of the duct. The ducts contain protein plugs which will later calcify to form pancreatic calculigenerally visible on $\mathrm{x}$-ray films of the abdomen, after some years of evolution (10-12); perineural inflammatory infiltration in fibrosis.

A morphometric ultrastructural study of the acinus and duct cells (17) has shown that the first lesion of CCP, before lesions of the duct and acinar cells, was the formation in the ducts of eosinophilic protein plugs. All transitions exist between these precipitates and calculi (commonly called calcifications) $(15,18-20)$.

Chronic calcifying pancreatitis, the most frequent chronic inflammatory disease of the pancreas is, therefore, a lithiasis which more resembles kidney lithiasis than alcoholic liver cirrhosis. As this disease has different causes and similar lesions, there must be some mechanism(s) common to all etiological forms, and others particular to each etiology.

\section{MECHANISMS COMMON TO DIFFERENT FORMS OF CCP}

Protein plugs at the origin of the disease are a build up of a fibrillar proteinaceous material $(20,21)$. Mature calculi contain calcium salts, mostly bicarbonate (calcite) and a small quantity of protein $(18-20,22)$. Morphological studies suggest that calculi originate from protein plugs by the deposition of calcite and a network of protein fibrils $(18,19)$. The protein material of plugs (23) and of calculi (22) is similar. This low molecular weight protein, pancreatic stone protein (PSP), isolated in the authors' laboratory is associated in calculi with an unidentified polysaccharide (22). The authors have shown that this composition was identical in the alcoholic, idiopathic and in the Indian juvenile tropical forms (24). In most calculi, calcium salts represent at least $95 \%$ of weight and are associated with small quantities of a soluble form of PSP. Nevertheless, giant calculi $(2 \mathrm{~cm})$ composed of pure calcite without PSP were observed in a nonalcoholic woman (25). Inversely, some rare calculi are composed only of an insoluble, probably degraded, molecular form of PSP which may later calcify, The pathogenesis of $\mathrm{CCP}$ raises, therefore, two problems; precipitation of calcium and precipitation of protein. Both problems are dominated by PSP.

Precipitation of calcium: Pancreatic juice is always saturated in calcium (26). This means that the real problem is to determine why calcium does not precipitate in normal subjects as it precipitates in patients presenting with CCP. It is necessary to assume the existence of one or more stabilizers in the normal pancre- 
atic juice, preventing the precipitation of calcium when it is saturated.

PSP is probably one of these stabilizers. This molecule is present in normal pancreatic juice as a group of proteins, molecular weight 15,000 to 19,000 (27). The molecule which is secreted by acinar cells is probably the heaviest one; it is glycosylated. It is synthetized as a unique amino acid chain in the endoplasmic reticulum of the acinar cell, which contains a specific messenger RNA for PSP (28). It is concentrated as enzymes in zymogen granules (29).

In pancreatic juice, the four heaviest molecular forms (PSP-S2 to S5) are hydrolyzed by trypsin (30) to a smaller form (PSP-S1), insoluble at physiological pH, nonactive in preventing calcium crystalization. The complete amino acid sequence of this form has been published (31). It is a 133 amino acid peptide and its sequence has no homology with the sequence of any other known protein, particularly pancreatic enzymes (27). PSP extracted from calculi probably has the same amino acid chain as PSP-S1, but is soluble at physiological $\mathrm{pH}$ and prevents calcilum crystallization. When a calcium chloride solution is added to a solution of sodium bicarbonate and different ions, (the concentration of which mimics the ionic composition of pancreatic juice), after a 2 to 3 min delay (nucleation time) a precipitate of calcium chloride (calcite) is formed. If adequate quantities of PSP are added before calcium chloride, no crystal precipitates are formed. When PSP is added after precipitation has started but before it is complete, the process stops immediately. Similar molecules preventing crystallization of calcium salts are already known in saliva (32) and urine (33). They act by blocking the growth sites of crystals, which indicates that one molecular form of PSP is found in almost pure conditions in pancreatic calcified calculi.

PSP exists in the pancreatic juice of all mammals studied in the authors' laboratory. A degraded form, insoluble at $\mathrm{pH} 7$, has been discovered in the ox pancreas and in the human pancreas by Gross and co-workers $(34,35)$. When PSP is measured in pure pancreatic juice by immunological techniques using polyclonal antibodies (Mancini immunodif- fusion [36], Elisa with a monoclonal antibody as first antibody and a polyclonal antibody as the second antibody [37]), its concentration is constantly decreased in patients presenting with CCP compared to normal controls. This suggests that a decrease of PSP secretion could be responsible for the formation of calcite calculi.

It is not known if this decrease is due to a congenital disturbance of the biosynthesis of PSP (the case of complete absence of PSP is probably due to this mechanism [25]), or to the biosynthesis of an abnormal molecule (abnormal sequence of amino acids or abnormal glycozylation). An in vivo degradation of PSP in pancreatic juice is improbable as PSP is strongly decreased in the zymogen granules of patients presenting with CCP compared to controls (29).

As soon as the duct epithelium is in contact with plugs or stones, the basal membrane disappears (38) and then the duct cell atrophies (15). This allows the transsudation of interstitial fluid, which increases the concentration of serum protein (39) and calcium (40) of pancreatic juice. This increased concentration of calcium, secondary to the first lesions of the disease, could explain why calculi frequently appear and grow at the end of years of clinical evolution $(10,11)$.

Precipitation of protein: Morphometric studies (17) have shown that the first visible lesion of the disease is the precipitation of protein. Biochemical studies (23) have shown that these proteins were formed by a degraded molecule insoluble at $\mathrm{pH} 7$, corresponding to PSP-S1

The assumption of the pathological secretion by acinar cells of an abnormal molecular form, less active and less soluble, could explain this fact, though this has not been demonstrated. It is, nevertheless, compatible with the finding that, if immunological estimation of PSP with polyclonal antibodies easily distinguishes patients presenting with CCP from normal patients $(36,37)$, immunological methods using a monoclonal antibody prepared in the authors' laboratory do not show differences between patients and controls $(37,41)$. This monoclonal antibody recognizes PSP-S1, the short, insoluble and inactive form of PSP.

\section{ETIOLOGICAL FORMS AND GEOGRAPHICAL DISTRIBUTION}

There are two areas of maximum frequency. In temperate countries, Europe, temperate zone of America, Africa, Japan $(42,43)$, the disease is most frequently observed in alcoholics having a high protein and fat consumption, especially males. Generally, the clinical evolution starts between 30 and 45 years of age. When the consumption of alcohol, protein and fat increases with time in an occidental country, with a delay of some years, an increased frequency of CCP is observed.

In certain tropical countries, CCP is observed in young adults (mean age 12 years) and nonalcoholics living in areas where protein and fat intakes are low (43), such as south India $(45,46)$. This tropical form, or fibrocalculous pancreatic diabetes (46), is also observed in certain countries of Africa, such as Zaire (47) and Nigeria $(48,49)$, but it is absent or exceptional in Senegal (50), Ivory Coast (51), Uganda (52) and Natal (53), where the origin is generally alcoholic. Some cases have been described in Brazil where the alcoholic form predominates (54).

CCP is observed in 5 to $7 \%$ of patients presenting with hypercalcemia secondary to hyperparathyroidism $(55,56)$ or other causes (57). There is an autosomal hereditary dominant form with variable penetrance observed in children of both sexes $(58,59)$. But also, more frequently than if by chance, one or two cases are observed at the adult age in the family of a patient presenting with CCP (6). Above, the authors have described exceptional forms: calculi of pure calcite without PSP and transparent calculi of degraded PSP without calcium. These forms are generally observed in young nonalcoholic women. It is, therefore, probable that CCP is, in reality, a group of different diseases.

\section{ALCOHOLIC CCP}

Anatomical form of alcoholic CCP: Two forms have been described: chronic pancreatitis, which is a chronic calcifying pancreatitis; and acute pancreatitis. One generally accepts that acute alcoholic pancreatitis is the exacerbation of the initial stages of chronic alcoholic pan- 
creatitis. It is observed in chronic alcoholics who have recently increased their consumption of alcohol (60). The followup of these patients generally shows that they will, after some years, develop pancreatic calcification (61). A recent study concluded that certain cases of acute alcoholic pancreatitis healed completely and were not followed by chronic pancreatitis (62). In the authors' opinion, this work proves only that the clinical onset of chronic pancreatitis appears at variable speeds after beginning alcohol consumption and does not allow either acceptance or rejection of the existence of acute alcoholic pancreatitis healing completely.

Alcohol, protein and fat consumption and risk of CCP: The authors have shown that there is a linear relationship between the logarithm of the risk of developing CCP and the average daily consumption of ethanol $(63,64)$. Risk in total abstainers is lower than in subjects consuming such low quantities as 1 to $20 \mathrm{~g}$ ethanol per day. This means that there is no statistical threshold of tolerance but rather a continuous spectrum of individual thresholds from idiopathic pancreatitis to pancreatitis observed in heavy alcoholics; and that only some people are able to develop an alcoholic pancreatitis and, therefore, that there must be a congenital or acquired predisposition to the disease. Duration of consumption of ethanol is also important.

There is also a linear relationship between protein intake and logarithm of the risk, but the effect of protein is weaker than that of ethanol. The effect of fat is more complex: lower risk for average diets ( 80 to $100 \mathrm{~g}$ fat per day) which should, therefore, be prescribed to patients with an increased risk. The action of protein, fat and ethanol are additive on the logarithm of the risk. Tobacco also probably increases the risk of developing $\mathrm{CCP}(65,66)$.

Modifications of pancreatic juice due to alcohol: Chronic alcoholism increases total concentration of protein (mostly secretory enzymes), decreases $\mathrm{pH}$, bicarbonate and citrate as well as the concentration of the secretory trypsin inhibitor and the ratio of cationic trypsinogen to anionic trypsinogen $(67,68)$.
Mechanisms of action of ethanol: Alcohol is metabolized by the pancreas (69) but there are no arguments showing that this metabolism could play a role in the formation of lesions; alcoholic pancreatitis is a lithiasis. Similarly, there is no actual proof showing that the action on gastric secretion, tone of the sphincter of Oddi, or release of hormonal peptides or acetyldehyde produced by ethanol metabolism, could play a role $(67,68)$.

On the contrary, in the dog and very probably in humans, acute alcohol consumption inhibits or stimulates pancreatic protein secretion according to its plasma concentration. This is produced by reflex mechanisms, the vagus nerve and nicotinic and muscarinic synapses being necessary (70). In cases of long duration (months or years) or alcohol consumption, the inhibitory reflex disappears which is responsible for an increased secretion of protein, very probably due to an increased cholinergic tone $(67,68,71)$. This increases the viscosity of pancreatic juice and creates an obstacle to the flow of juice.

\section{TROPICAL CCP}

Epidemiological studies allow the comparison of the frequency of the disease as a function of diets in tropical countries $(67,68)$. These studies are not favourable to a possible role of kwashiorkor, nor of the consumption of manioc or cassava which have been suggested. The only factors which seems to be statistically linked to the disease are birth and life in areas of malnutrition and a very low fat diet. Low protein diet, if it plays a role, does not seem to be sufficient. A recent assumption based on rat experiments is that protein deficiency of the mother is responsible for an increased secretion of protein, continuing for a long time after weaning (72).

Besides tropical calcifying pancreatitis, one finds in certain tropical countries a completely latent pancreatic insufficiency which probably affects all of the population (73).

\section{HYPERCALCEMIC CCP}

The pancreatic juice of patients presenting with hypercalcemia, for example that of alcoholics, has an abnormally high concentration of protein $(74,75)$. The mechanism of this protein hypersecretion is complex: increased release of cholecystokinin (76); decreased sensitivity of duct cells to secretin (77); increased sensitivity of acinar cells to cholinomimetics and cholecystokinin (78).

\section{PREDISPOSITION FACTORS}

Not all alcoholics or all subjects submitted to hypercalcemia or living in tropical areas develop pancreatitis. It is, therefore, necessary to assume a predisposition. It is probable that the risk of another case in the family is greater for patients presenting with a CCP than in the general population (79). A higher risk is associated with blood group $\mathrm{O}$ $(80,81)$; however, data on the HLA groups are contradictory (68).

The knowledge of chronic pancreatitis has progressed considerably over the years. Distinction from acute pancreatitis, the evolution of which is different even if it recurs; definition of different forms of chronic pancreatitis presenting with different lesions and causes; demonstration of nutritional risk factors and overall new molecular basis, indicate that this knowledge will continue to progress at accelerated speed in the following months and years.

\section{REFERENCES}

1. Comfort MS, Gambill EE, Baggenstoss $\mathrm{AH}$. Chronic relapsing pancreatitis: $\mathrm{A}$ study of 29 cases without associated disease of the biliary or gastrointestinal tract. Gastroenterology 1946;6:239-85.

2. Odaira C, Berger Z, lovanna J, Sarles H. Localized necrohemorrhagic pancreatitis in the rat after pancreatic interstitial trypsin injection. Regressive pseudochronic lesions. Digestion 1986;34:68-77.

3. Lechene de la Porte P, lovanna J, Berger Z, Odaira C, Choux R, Sarles H. The cells of tubular complexes participate in the regeneration after acute pancreatitis. Digestion 1987;38:35.

4. Uscanga L, Kennedy RH, Choux R, Druguet M, Grimaud JA, Sarles H. Sequential connective matrix changes in experimental acute pancreatitis. An immunohistochemical and biochemical assessment in the rat. Int J Pancreatol $1987 ; 2: 33-45$.

5. Elsasser HP, Adler G, Kern HF. Time course and cellular source of pancreatic regeneration following acute pancreatitis in the rat. Pancreas 1986;1:421-9. 
6. Sarles H, Sarles JC, Camatte R. Observations on 205 confirmed cases of acute pancreatitis, recurring pancreatitis and chronic pancreatitis. Gut 1965;6:545-59.

7. Sarles H. Pancreatitis. Symposium in Marseille 1963. Karger ed. Basel, 1965.

8. Gyr K, Singer MV, Sarles H, eds. Pancreatitis, Concepts and Classification. Amsterdam: Excerpta Medica, 1984.

9. Gruber GB. Bauschspeiheldruse. In:Handbuch der Speziellen Pathologischen Anatomie und Histologie. Hencke F, Lubarsch D, eds. Berlin: Springer, 1929.

10. Bernades P, Belghiti J, Athouel M, Mallardo N, Breil P, Fekete F. Histoire naturelle de la pancreatite chronique. Etude de 120 cas. Gastroenterol Clin Biol 1983;7:8-13

11. Ammann RW, Akovbiantz A, Largiader F, Schueller G. Course and outcome of chronic pancreatitis. Longitudinal study of a mixed medical-surgical series of 245 patients. Gastroenterology 1984;86:820-8.

12. Ink O, Labayle D, Buffet C, Chaput JC, Etienne JP. Pancreatite chronique alcoolique: Relations de la douleur avec le sevrage et la chirurgie pancreatique. Gastroenterol Clin Biol 1984;8:419-25.

13. Nakamura K, Sarles H, Payan H. Three-dimensional reconstruction of the pancreatic ducts in chronic pancreatitis. Gastroenterology 1972;62:942-9.

14. Akao S, Bockman DE, Lechene de la Porte P, Sarles H. Three-dimensional pattern of ductuloacinar associations in normal and pathological human pancreas. Gastroenterology 1986;90:661-8.

15. Payan H, Sarles H, Demirdjian M, Gauthier AP, Cros RC, Durbec JP. Study of the histological features of chronic pancreatitis by correspondance analysis. Identification ... Entity. Biomedicine 1972;18:663-70.

16. Sahel J, Cros C, Durbec JP. Multicenter pathological study of chronic pancreatitis. Morphological regional variations and differences between chronic calcifying pancreatitis and obstructive pancreatitis. Pancreas 1986;1:471-7.

17. Tasso E, Stemmelin N, Sarles H, Clop J. Comparative morphometric study of the human pancreas in its normal state and in primary chronic calcifying pancreatitis. Biomedicine 1973;18:134-44.

18. Harada H, Takeda M, Tanaka J, Miki H, Ochi K, Kimura I. The fine structure of pancreatic stones as shown by scanning electron microscopy and X-ray probe microanalyser. Gastroenterol Jpn 1983; 18:530-7.

19. Bockman DE, Kennedy RH, Multigner L, de Caro A, Sarles H. Fine structure of the organic matrix of human pancreatic stones. Pancreas 1986;1:204-10.

20. Harada H, Ueda O, Yasuoka M Scanning electron microscopic studies on protein plugs obtained from patients with chronic pancreatitis. Gastroenterol Jpn 1982;17:98-101.

21. Kern HF, Warshaw AL, Scheele GA. Fine structure of protein precipitations in acinar lumina of the normal human pancreas and in chronic pancreatitis. In: Gyr K, Singer MV, Sarles H, eds. Pancreatitis, Concepts and Classification. Amsterdam :ExcerptaMedica, 1984:101-5.

22. de Caro A, Lohse J, Sarles H. Characterization of a protein isolated from pancreatic calculi of men suffering from chronic calcifying pancreatitis. Biochem Biophy Res Commun 1979;87:1176-82.

23. Guy O, Robles-Diaz G, Adrich Z, Sahel J, Sarles H. Protein content of precipitates present in pancreatic juice of alcoholic subjects and patients with chronic calcifying pancreatitis. Gastroenterology 1983;84:102-7.

24. de Caro A, Multigner L, Pitchumoni CS, Geevarghese PJ. Identification of the pancreatic stone protein in stones from tropical Indian pancreatitis. Gastroenterology 1985;88:1360. (Abst)

25. Sarles H, de Caro A, Multigner L, Martin E. Giant pancreatic stones in teetotal women due to absence of the 'stone protein'? Lancet 1982;ii: 714-5.

26. Moore EW, Verine HJ. Pancreatic calcification and stone formation: A thermodynamic model of calcium in pancreatic juice. Am J Physiol 1987;252:707-18

27. Montalto G, Bonicel J, Multigner L, Rovery M, Sarles H, de Caro A. Partial amino-acid sequence of human pancreatic stone protein. A novel pancreatic secretory protein. Biochem J 1986;238:227-32.

28. Giorgi D, Bernard JP, de Caro A Pancreatic stone protein. Evidence that it is encoded by a pancreatic messenger ribonucleic acid. Gastroenterology 1985;89:381-6.

29. Lechene de la Porte P, de Caro A, Lafont H, Sarles H. Immunocytochemical localization of pancreatic stone protein in the human digestive tract. Pancreas 1986;1:301-8.

30. Rouimi P, Bonicel J, Rovery M, de Caro A. Cleavage of the arg-ile bond in the native polypeptide chain of human pancreatic stone protein. FEBS Lett 1987;216:195-9.

31. de Caro A, Bonicel J, Rouimi P, de Caro J, Sarles H, Rovery M. Complete amino acid sequence of an immunoreactive form of human pancreatic stone protein isolated from pancreatic juice. Eur J Biochem 1987; 168:201-7.

32. Hay DI, Moreno E, Schlesinger $\mathrm{IH}$. Phosphoprotein inhibitors of calcium phosphate precipitation from salivary secretion. Inorg Presp Biol Med $1979 ; 2: 271-85$
33. Nagakawa Y, Abram U, Kerby FJ, Kaiser FT, Coe SL. Purification and characterization of the principal inhibitor of calcium oxalate mono hydrate crystal growth in human urines. J Biol Chem 1983;258:1259-60.

34. Gross J, Brauer AW, Bringhurst RF, Corbett C, Margolies MN. An unusual bovine pancreatic protein exhibiting $\mathrm{pH}$-dependent globule-fibril transformation and unique amino acid sequence. Proc Nat Acad Sci USA 1985;82:5627-31.

35. Gross J, Carison RI, Brauer AW, Margolies MN, Warshaw AL, Wands JR Isolation, characterization and distribution of an usual pancreatic human secretory protein. JClin Invest 1985; 76:2225-6

36. Multigner L, Sarles H, Lombardo D, de Caro A. Pancreatic stone protein. Implication in stone formation during the course of chronic calcifying pancreatitis. Gastroenterology 1985;89:387-91.

37. Provansal-Cheylan M, Mariani A, Dupuis P, Sarles H. Pancreatic juice and serum samples by enzyme linked immunosorbent assay and comparison with two other methods. Digestion 1987;38:53-4. (Abst) (In press)

38. Kennedy RH, Bockman DE, Uscanga L, Choux R, Grimaud JA, Sarles H. Pancreatic extracellular matrix alterations in chronic pancreatitis. Pancreas 1987;2:61-72.

39. Clemente F, Ribiero L, Figarella C, Sarles H. Albumine IGA et IGG dans le suc pancreatique humain normal chez l'adulte. Clin Chim Acta 1971;33:317-24

40. Gullo L, Sarles H, Mott CB, Tiscornia OM, Pauli AM, Pastor J. Pancreatic secretion of calcium in healthy subjects and various diseases of the pancreas. Rendiconti Gastroenterol 1974;6:35-44.

41. Schmiegel WH, Burchert M, Kalthoff H. Pancreatic stone protein in serum of patients with pancreatitis. Lancet 1986;ii:686-7.

42. Sarles $H$. An international survey of nutrition and pancreatitis. Digestion 1973:9:389-403.

43. Sarles H, Cros RC, Bidart JM, International Group for the Study of Pancreatic Diseases. A multicenter inquiry into the etiology of pancreatic diseases. Digestion 1979;19:110-25.

44. Geevarghese PJ. Calcific pancreatitis. Causes and mechanisms in the tropics compared with those in the subtropics. Bombay: Varghese Publishing House, 1986.

45. Vakil RJ. Chronische pankreatitis in indien. Leber Magen Darm 1976;6: 276-81.

46. Mohan V. Diabetes in the tropics. In: Desfonzo RA, Alberti KGMM, Keen $\mathrm{H}$, Limmeth P, eds. International Text Book of Diabetes Mellitus. John Prisley and Sons Publisher, 1988.

47. Sonnet J, Brisbois P, Bastin JP. Chronic 
pancreatitis with calcification in congolese bantus. Trop Geogr Med 1960;18:97-113.

48. Olurin EO, Oyinade, Olurin. Pancreatic calcification: A report of 45 cases. $\mathrm{Br}$ Med J 1969:4:534-9.

49. Osuntokun BO. The neurology of non-alcoholic pancreatic diabetes mellitus in Nigerians. J Neurol Sci 1970;11:17-43.

50. Carayon A, Onde M, Rousselet M. Evolution de la pathologie pancreatique de l'africain (a propos de 26 observations). Bull Soc Med Afr 1967;12:287-93.

51. Sauniere JF, Sarles H, Attia Y. Exocrine pancreatic function of children from the Ivory Coast compared to French children. Effect of kwashiorkor. Dig Dis Sci 1986;311:481-6.

52. Shaper AG, Aetiology of chronic pancreatic fibrosis with calcification seen in Uganda. Br Med J 1964;1:1607-9.

53. Moshal MG. A study of chronic pancreatitis in Natal. Digestion 1973;9:438-46.

54. Dani R, Penna F, Nogueira CED. Etiology of chronic calcifying pancreatitis in Brazil : A report of 329 consecutive cases. Int J Pancreatol 1986;1:399-406

55. Mixter CG, Keyner WM, Cope O. Further experience with pancreatitis as a diagnosis due to hyperparathyroidism. N Engl J Med 1962;266:265-72.

56. Dubost C, Testart J, Choquart P, Kaswin R. Les pancreatites de l'hyperparathyroidie. Gastroenterol Clin Biol 1979;3:621-30.

57. Izsak EM, Shike M, Roulet M, Jeejeebhoy KN. Pancreatitis in association with hypercalcemia in patients receiving total parental nutrition. Gastroenterology 1980;79:555-8.

58. Comfort MW, Steinberg AG. Pedegree of a family with hereditary chronic relapsing pancreatitis. Gastroenterology 1952:21:54-63.

59. Stafford RJ, Grand RJ. Hereditary disease of the exocrine pancreas. Clin Gastroenterol 1982;11:141-70.

60. Kager L, Lindberg S, Agren S. Alcohol consumption and acute pancreatitis in men. Scand J Gastroenterol 1972:7:15

61. Gullo L, Durbec JP. Epidemiology of chronic pancreatitis. Alcohol and dietary habits. In: Gyr, KE, Singer MV, Sarles H, eds. Pancreatitis, Concepts and Classification. Amsterdam: Excerpta Medica, 1984:371-6.

62. Ammann RW, Buehler R, Bruehlmann W, Kehl D, Muench R, Stamm B. Acute (nonprogressive) alcoholic pancreatitis: Prospective longitudinal study of 114 patients with recurrent alcoholic pancreatitis. Pancreas 1986;1:195-203.

63. Durbec JP, Sarles H. Multicenter survey of the etiology of pancreatic diseases. Relationship between the relative risk of developing chronic pancreatitis and alcohol protein and lipid consumption. Digestion 1978;18:337-50.

64. Durbec JP, Bidart JM, Sarles H. Interaction between alcohol and other foodstuffs. Epidemiological aspects. Colloques Inserm 1980;93:33-52.

65. Yen S, Hsieh CC, Macmahon B. Consumption of alcohol and tobacco and other risk factors for pancreatitis. Am J Epidemiol 1982;116:407-14.

66. Lowenfels AB, Zwemer FL, Jhangiani S, Pithumoni CS. Pancreatitis in a Native American Indian population. Pancreas 1987;2:694-7.

67. Sarles H, Lawgier R, Boustiere C. Pancreatic lithiasis. Alcoholic pancreatic pathogenesis. In: Jerzy GB, Sherlock P, eds. Progress in Gastroenterology. New York: Grune and Stratton, 1983:189-212.

68. Sarles H. Etiopathogenesis and definition of chronic pancreatitis. Dig Dis Sci 1986;31:915-1075.

69. Clemente F, Estival A, Durand S, Ribet A. Biochemical events in rat pancreatic cells in acute and chronic alcohol intoxications. In: Gyr KE, Singer MV, Sarles H, eds. Pancreatitis, Concepts and Classification. Amsterdam: Excerpta Medica, 1984:111-6.

70. Noel Jorand MC, Sarles H. Simultaneous mechanisms on exocrine pancreatic secretion initiated by alcohol in the conscious dog. Dig Dis Sci 1983;28:879-88.
71. Tiscornia OM, Palasciano G, Sarles H Effects of chronic ethanol administration on canine exocrine pancreatic secretion. Further studies. Digestion 1974;11:172-82.

72. Sarles H, Lahaie R, Dollet JM, Beck B, Michel R, Debry G. Effect of parental malnutrition on enzyme content of rat pancreas. Dig Dis Sci 1987;32:520-8.

73. Sauniere JF, Sarles H. Exocrine pancreatic function and protein-calorie malnutrition in Dakar and Abidjan (West Africa). Silent pancreatic insufficiency. Am J Clin Nutr. (In press)

74. Goebell $\mathrm{H}$. The role of calcium in pancreatic secretion and disease. Acta Hepatogastroenterol 1976;23:151-61.

75. Noel-jorand MC, Verin H], Sarles H. Dose-dependent and long-lasting effects of repeated intravenous injections of calcium on the canine secretinstimulated pancreatic juice secretion. Eur J Clin Invest 1981;11:25-31.

76. Layer P, Hotz J, Eysselein VE, Jansen JBMJ, Lamers CBHW, SchmitzMoormann HP. Effects of acute hypercalcemia on exocrine pancreatic secretion in the cat. Gastroenterology 1985:88:1168-74.

77. Noel-Jorand MC, Schmidt DN, Devaux MA, Sarles H. Response of the exocrine pancreas to graded doses of secretin in calcium-treated and normal dogs. Regul Pept 1981:2:181-91.

78. Noel-Jorand MC. Schmidt DN, Devaux MA, Sarles H. Repeated IV injections of calcium salts give rise to increased exocrine pancreatic cell sensitivity to caerulein and urecholine in the dog. Biomed Parmacol 1983;37:129-35.

79. Sarles H, Camatte R. Ethiopathogenesis of pancreas. In: Recent Advances in Gastroenterology. Proceedings of 3rd World Congress of Gastroenterology. Tokyo, 1966.

80. Marks IN, Bank S, Louw JH. Chronic pancreatitis in the Western Cape. Digestion 1973;9:447-53.

81. Gullo L, Costa PI, Labo G. Chronic pancreatitis in Italy. Aetiological, clinical and histological observations based on 253 cases. Rendiconti Gastroenterol 1977;9:97-104. 


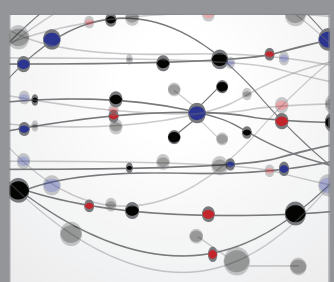

The Scientific World Journal
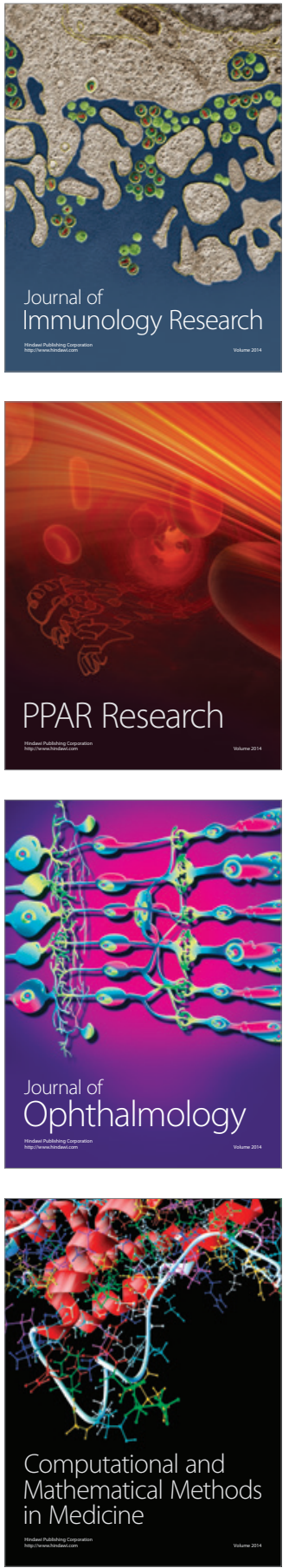

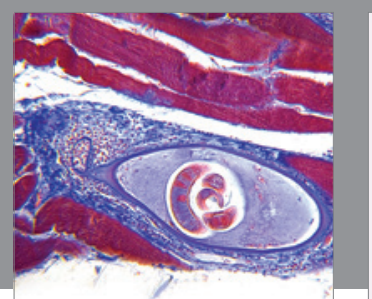

Gastroenterology Research and Practice

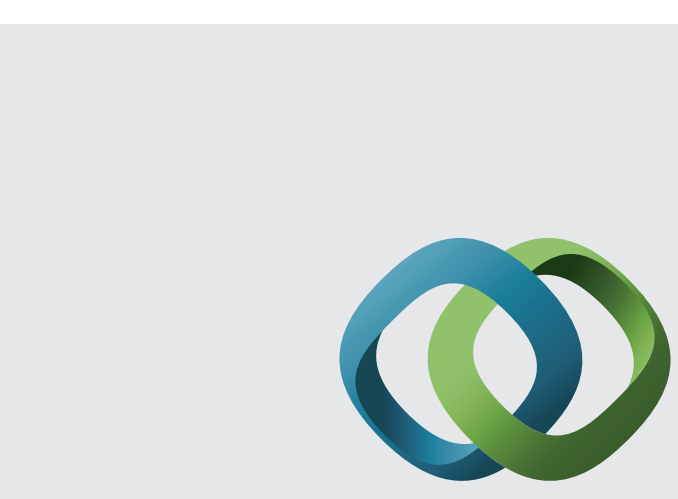

\section{Hindawi}

Submit your manuscripts at

http://www.hindawi.com
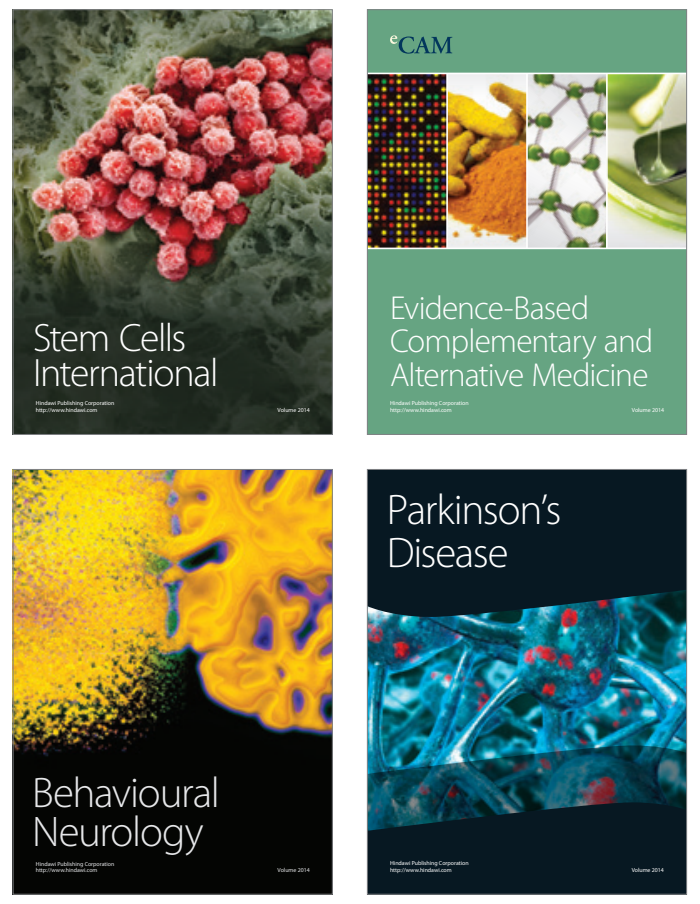
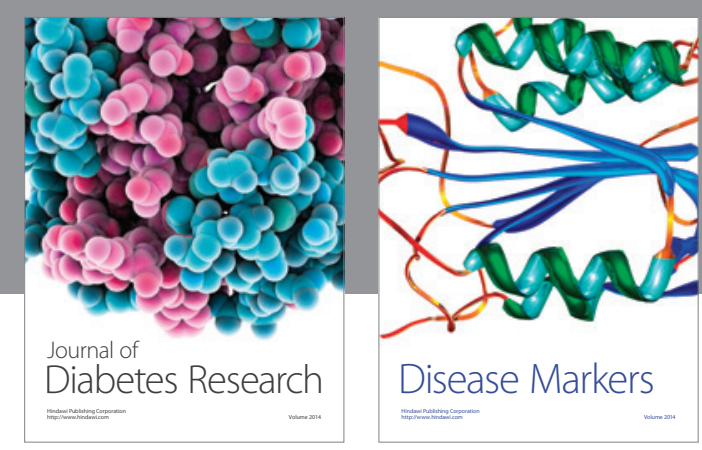

Disease Markers
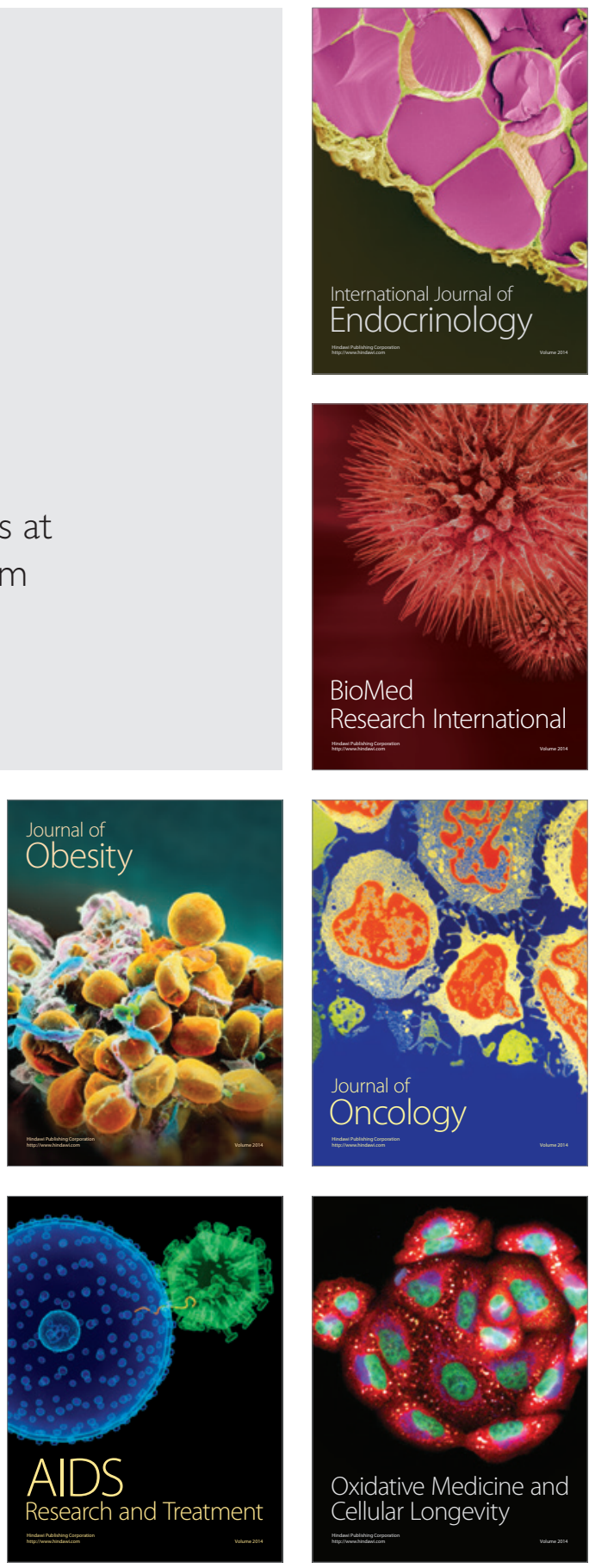